\title{
A multi-century ice-core perspective on 20th-century climate change with new contributions from high-Arctic and Greenland (PARCA) cores
}

\author{
Ellen MOSLEY-THOMPSON, ${ }^{1,2}$ Lonnie G. THOMPSON, ${ }^{1,3}$ Ping-Nan LIN ${ }^{1}$ \\ ${ }^{1}$ Byrd Polar Research Center, The Ohio State University, 1090 Carmack Road, Columbus, OH 43210-1002, USA \\ E-mail: thompson.4@osu.edu \\ ${ }^{2}$ Department of Geography, The Ohio State University 1036 Derby Hall, 154 North Oval Mall, Columbus, \\ OH 43210-1361, USA \\ ${ }^{3}$ Department of Geological Sciences, The Ohio State University, 275 Mendelhall Laboratory, 125 South Oval Mall, \\ Columbus, OH 43210-1308, USA
}

\begin{abstract}
A global collection of high temporally resolved ice-core-derived $\delta^{18} \mathrm{O}$ records is examined to assess whether the proxy records are consistent with contemporaneous observed temperature variations in their respective regions. This is prerequisite to using the older parts of the proxy $\left(\delta^{18} \mathrm{O}\right)$ records to assess whether 20th-century temperatures remain within the range of longer-term natural variability. Excluding the high plateaus in East and West Antarctica where 20th-century temperatures show modest cooling, the ice-core records from other regions suggest modest to strong 20th-century warming. The recent warming over Greenland has been modest and spatially variable. The 20th-century warming over both the Barents Sea region and the Tibetan Plateau now falls well outside the range of prior longer-term temperature variability. Similarly, over the South American Andes and the Antarctic Peninsula the recent warming exceeds the long-term mean for the last 1000 and 500 years, respectively. The ice fields in these regions are in danger of being compromised or lost if the present warming trend in these regions persists.
\end{abstract}

\section{INTRODUCTION}

Since the late 1960s when the first long cores were recovered from Greenland and Antarctica, ice cores have provided unique details about the nature of the Earth's climate system with emphasis on glacial-interglacial cycles. Recently, greater attention has been focused on reconstructing high-resolution (optimally annual) proxy histories for the Holocene, with emphasis on the last few thousand years. This attention results, in part, from the need to assess the well-documented 20th-century warming of the Earth's surface temperatures from a longer-term perspective (Mann and others, 1999; Levitus and others, 2000; Hansen and others, 2001; Jones and Moberg, 2003; Moberg and others, 2005). Restricted to very cold and/or high locations, ice-corederived proxy histories provide a partial picture of past climatic and environmental conditions. These frozen archives are powerful contributors to multi-proxy reconstructions, providing multiple lines of evidence (e.g. changes in atmospheric dustiness and chemistry, in mass accumulation and in temperature) from remote locations where other proxy data are unavailable.

Over the last few decades, the Ice Core Paleoclimate Research Group at The Ohio State University (OSU) has collected a suite of tropical and subtropical cores from the South American Andes and the Tibetan Plateau, as well as polar cores from Antarctica, Greenland and Franz Josef Land (FJL), Russian Arctic. The analyses of these ice cores have emphasized the highest time resolution possible. More recently, a number of new annually resolved ice-core records from Greenland have been added to the OSU collection. The cores were acquired between 1995 and 1999 as part of the NASA-NSF (US National Science Foundation) PARCA (Program for Arctic Regional Climate Assessment) project (Thomas and others, 2001). These cores are particularly valuable as they come from sites that are widely distributed along the western side of Greenland. Previously, most available high-resolution Greenland ice-core histories that extend back more than a century were drilled in central and north-central Greenland or in southern Greenland near the Dye 2 and Dye 3 radar stations (now abandoned).

\section{ICE-CORE-DERIVED $\delta^{18} \mathrm{O}$ RECORDS}

Figure 1 presents the decadally averaged $\delta^{18} \mathrm{O}$ records organized geographically (north to south), along with regional maps showing their locations. The records from Tibet, the Andes and Antarctica have been published separately, but not collectively with the newer $\delta^{18} \mathrm{O}$ histories from Greenland and FJL. This synthesis is limited to the last millennium, as many of the records are relatively short, extending back just a few centuries to one half-millennium. Six of the $\delta^{18} \mathrm{O}$ records extend to earlier millennia, four into the Last Glacial Stage. The longer records include those from the Dunde and Guliya ice cores from the Tibetan Plateau (Thompson and others, 1989, 1997, respectively), the Quelccaya and Huascarán cores from Peru (Thompson and others, 1986, 1995, respectively), the Sajama ice cap in Bolivia (Thompson and others, 1998) and the Plateau Remote site from East Antarctica (Mosley-Thompson, 1996). Table 1 provides basic information about each core. Details of the dating procedures are in the references.

The $\delta^{18} \mathrm{O}$ histories from two different drilling projects at the Summit Site in central Greenland are included for comparison with the newer Greenland records (Fig. 1). The Greenland Ice Sheet Project 2 (GISP2) record (Grootes and others, 1993) is shown along with a composite from two 

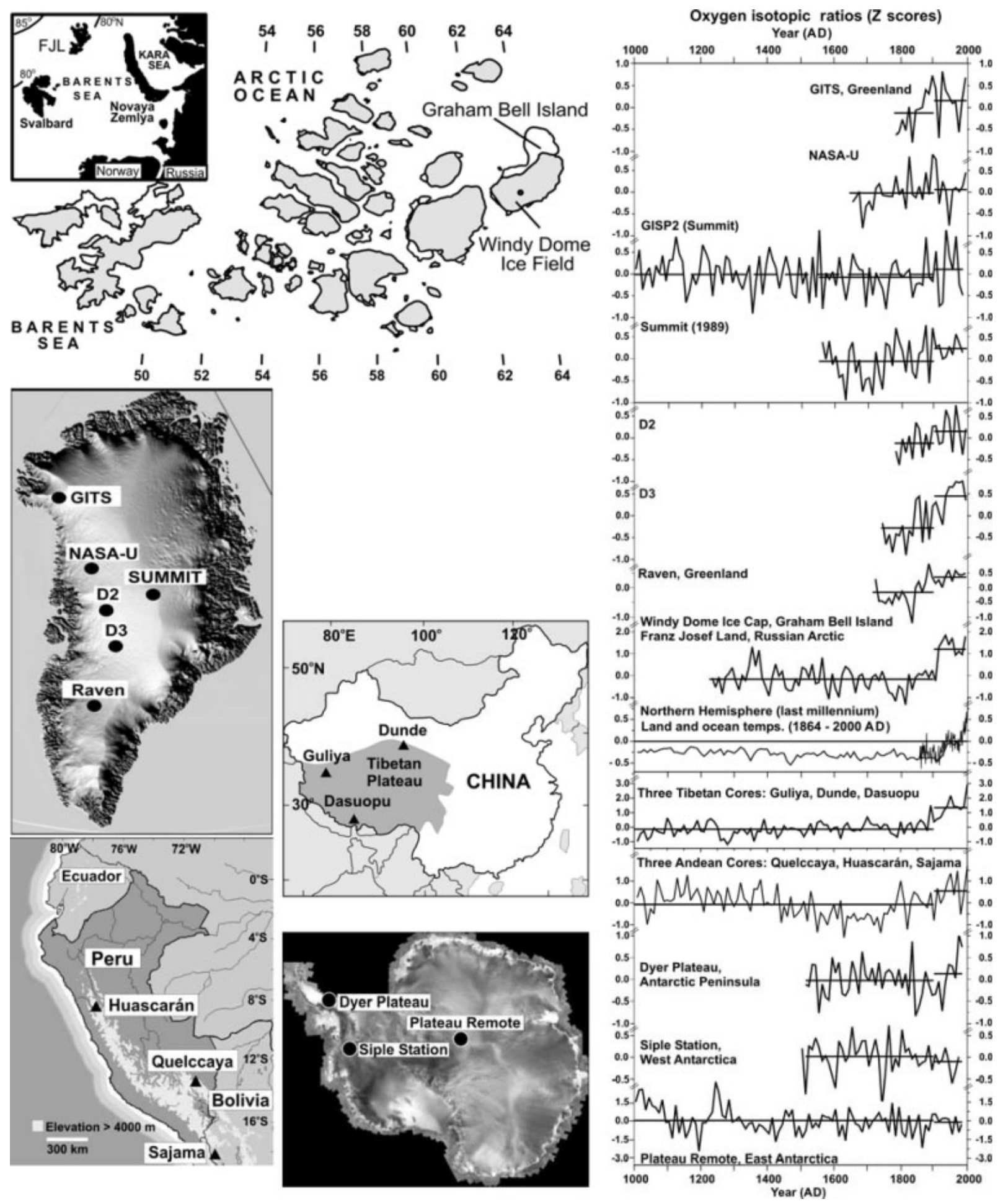

Fig. 1. Decadally averaged $\delta^{18} \mathrm{O}$ histories are shown from north to south (top to bottom). Horizontal bars in each record show the average $\delta^{18} \mathrm{O}$ values for the pre- and post-1900 time intervals. The 1000 year Northern Hemisphere reconstruction is from Mann and others (1999) and updated by Mann and Jones (2003). Superimposed is the observed near-surface temperature record (Jones and Moberg, 2003). Maps show locations for the cores.

cores, called Site T cores, drilled $4 \mathrm{~km}$ apart at the Summit in 1989 by OSU (Mosley-Thompson and others, 1993). The $\delta^{18} \mathrm{O}$ history from the Windy Dome Ice Field on Graham Bell Island, FJL, (Henderson, 2002) is included along with the five new Greenland $\delta^{18} \mathrm{O}$ histories: GITS, NASA-U, D2, D3, Raven (Fig. 1), collected by the PARCA initiative. With the exception of the GISP2 core, all records discussed here were analyzed and dated by the authors using consistent procedures. Moreover, unlike many of the earlier Greenland records, the timescales for the PARCA cores were constructed using three seasonally varying parameters: the insoluble dust concentrations and oxygen isotopic ratios $\left(\delta^{18} \mathrm{O}\right)$, both measured at OSU, and hydrogen peroxide $\left(\mathrm{H}_{2} \mathrm{O}_{2}\right)$ measured at the University of Arizona (McConnell and others, 2001). The timescales were further confirmed with beta radioactivity horizons from thermonuclear bomb tests and by identification of known volcanic eruptions (Mosley-Thompson and others, 2001, 2003). 
Table 1. Information for all ice cores discussed in the text

\begin{tabular}{|c|c|c|c|c|c|c|c|c|}
\hline Core name & Lat. & Long. & $\begin{array}{c}\text { Elevation } \\
\text { m }\end{array}$ & Year drilled & $\begin{array}{c}\text { Bottom depth } \\
\text { m }\end{array}$ & Bottom age & $\begin{array}{c}\text { Ave. accum. } \\
\text { m w.e. }\end{array}$ & Source \\
\hline GITS & $77.14^{\circ} \mathrm{N}$ & $61.09^{\circ} \mathrm{W}$ & 1887 & 1996 & 120.50 & AD 1745 & 0.350 & M-T (2001) \\
\hline NASA-U & $73.84^{\circ} \mathrm{N}$ & $49.50^{\circ} \mathrm{W}$ & 2369 & 1995 & 151.24 & AD 1645 & 0.332 & M-T (2001) \\
\hline Site D2 & $71.75^{\circ} \mathrm{N}$ & $46.16^{\circ} \mathrm{W}$ & 2640 & 1999 & 132.40 & AD 1781 & 0.450 & M-T (2003) \\
\hline Summit GISP2 & $72.57^{\circ} \mathrm{N}$ & $38.50^{\circ} \mathrm{W}$ & 3210 & 1990-93 & 3053.44 & $>100000$ вР & 0.222 & Grootes (1993) \\
\hline Summit Site T & $72.58^{\circ} \mathrm{N}$ & $38.45^{\circ} \mathrm{W}$ & 3200 & 1989 & 200.00 & AD 1212 & 0.222 & M-T (1993) \\
\hline Site D3 & $69.80^{\circ} \mathrm{N}$ & $44.00^{\circ} \mathrm{W}$ & 2560 & 1999 & 150.73 & AD 1740 & 0.450 & M-T (2003) \\
\hline Raven & $69.50^{\circ} \mathrm{N}$ & $44.50^{\circ} \mathrm{W}$ & 2053 & 1988 & 120.96 & AD 1717 & 0.326 & M-T (2003) \\
\hline Franz Josef & $80.73^{\circ} \mathrm{N}$ & $63.53^{\circ} \mathrm{E}$ & 509 & 1997 & 314.80 & AD 1225 & 0.590 & Henderson (2002) \\
\hline Dunde & $38.10^{\circ} \mathrm{N}$ & $96.40^{\circ} \mathrm{E}$ & 5325 & 1987 & 139.80 & 〜40 000 years* & 0.380 & Th (1989) \\
\hline Guliya & $35.28^{\circ} \mathrm{N}$ & $81.48^{\circ} \mathrm{E}$ & 6200 & 1992 & 308.60 & $>500000$ years & 0.220 & Th (1997) \\
\hline Dasuopu & $28.38^{\circ} \mathrm{N}$ & $85.72^{\circ} \mathrm{E}$ & 7200 & 1997 & 167.70 & 〜8000 years & 1.000 & Th (2000) \\
\hline Huascarán & $9.11^{\circ} \mathrm{S}$ & $77.62^{\circ} \mathrm{W}$ & 6048 & 1993 & 166.10 & 〜19000 years & 1.300 & Th (1995) \\
\hline Sajama & $18.10^{\circ} \mathrm{S}$ & $68.88^{\circ} \mathrm{W}$ & 6542 & 1997 & 132.80 & $\sim 25000$ years & 0.440 & Th (1998) \\
\hline Dyer Plateau & $70.34^{\circ} \mathrm{S}$ & $64.87^{\circ} \mathrm{W}$ & 2002 & 1989-90 & 235.20 & AD 1505 & 0.440 & Th (1994) \\
\hline Siple Station & $75.92^{\circ} \mathrm{S}$ & $84.25^{\circ} \mathrm{W}$ & 1054 & 1985 & 303.00 & AD 1417 & 0.461 & M-T (1992) \\
\hline Plateau Remote & $84.72^{\circ} \mathrm{S}$ & $43.00^{\circ} \mathrm{E}$ & 3330 & 1986 & 200.00 & 〜4000 years & $\sim 0.040$ & M-T (1996) \\
\hline
\end{tabular}

Note: M-T: Mosley-Thompson first author; Th: Thompson first author.

*Timescale under revision.

To facilitate their comparison, each record has been normalized with respect to its entire length (for cores shorter than one millennium) or with respect to the last millennium for the longer cores. The annual $Z$ score is the standardized deviation from its respective mean (annual $Z$ score $=($ annual value-record mean)/record standard deviation). The annual $Z$ scores are shown (Fig. 1) as unweighted 10 year (decadal) averages plotted at the midpoint of the decade. The goal here is to examine a global (pole-to-pole) array of ice-core-derived $\left(\delta^{18} \mathrm{O}\right)$ proxy temperature histories to assess 20th-century climate changes within a longer-term perspective. Thus, the averages for the pre-1901 period (1900 to the oldest year in the record or $\mathrm{AD} 1000)$ are compared with those from the post-1900 part of the record (1901 to the most recent year in the record). It would be ideal if all the records were of equivalent temporal length; however, the time, expense and logistics required to collect ice cores dictates the depth to which cores are recovered at a given site.

Before comparing the $\delta^{18} \mathrm{O}$ records and drawing general conclusions, the advantages and limitations of using $\delta^{18} \mathrm{O}$ as a proxy for regional air temperature are reviewed briefly. With respect to ice cores, the $\delta^{18} \mathrm{O}$-air-temperature $\left(T_{\mathrm{a}}\right)$ relationship has been most extensively investigated in Greenland and Antarctica. In Antarctica, a strong linear relationship between $\delta^{18} \mathrm{O}$ and $T_{\mathrm{a}}$ has been demonstrated (Aldaz and Deutsch, 1967; Mosley-Thompson, 1992; Peel, 1992; Jouzel, 1999), with slope $(\alpha)$ values ranging from 0.76 to $0.92 \%{ }^{\circ} \mathrm{C}^{-1}$. In Greenland the slope of the linear relationship ranges from 0.62 to $0.67 \%{ }^{\circ} \mathrm{C}^{-1}$ (Dansgaard and others 1973; Johnsen and others, 1989). More recently, using central Greenland borehole temperatures, Cuffey and others (1995) calibrated the paleothermometer, $\delta^{18} \mathrm{O}=$ $\alpha T_{\mathrm{a}}+\beta$. They concluded that $\delta^{18} \mathrm{O}$ provides a 'faithful' proxy for long-term average temperature at that site (GISP2); however, they caution that it is inappropriate to use a single set of constants $(\alpha$ and $\beta$ ) to infer past climate changes, as they depend upon factors that change with time. Thus, in keeping with the general practice in ice-core paleothermometry (Jouzel and others, 1997; Jouzel, 1999), we adopt the convention for the polar cores such that more negative $\delta^{18} \mathrm{O}$ values reflect cooler air temperatures and less negative $\delta^{18} \mathrm{O}$ values reflect warmer air temperatures at the time of condensation.

There has been much less investigation of the $\delta^{18} \mathrm{O}-T_{\mathrm{a}}$ relationship in non-polar ice cores, in part because records have been limited. Rozanski and others (1992, 1993) reviewed an extensive set of in situ data collected over three decades, mainly from mid-latitude, lower-elevation sites. They suggested that as a first approximation, temperature controls the isotopic composition of precipitation at high and mid-latitudes while the amount of precipitation (the amount effect) controls the isotopic composition in tropical regions (Rozanski and others, 1997). They also concluded that the relationship between longer-term changes in $\delta^{18} \mathrm{O}$ and $T_{\mathrm{a}}$ for a given location is more appropriate for paleoclimate investigations (vs short-term applications).

Additional studies have addressed the roles of air temperature and the precipitation 'amount effect' in determining the $\delta^{18} \mathrm{O}$ values in precipitation (snowfall) from a regional perspective. Yao and others (1996) conducted the first study of the $\delta^{18} \mathrm{O}-T_{\mathrm{a}}$ relationship in discrete precipitation events at three sites on the Tibetan Plateau. They reported that averaging $\delta^{18} \mathrm{O}$ and air temperatures for discrete precipitation events over longer periods (months to years) removed the synoptic effects and pointed to air temperature as the dominant control on longer-term $\delta^{18} \mathrm{O}$ variations at individual sites.

Thompson and others (2000) address the conundrum with Andean precipitation whereby the seasonal $\delta^{18} \mathrm{O}-T_{\mathrm{a}}$ relationship is opposite that in the polar regions. In the Andes, summer snow has more negative $\delta^{18} \mathrm{O}$ values than winter snow, and the seasonal $\delta^{18} \mathrm{O}$ range can be large, up to $20 \%$, although the seasonal temperature range is small. Grootes and others (1989) used a three-step model, employing Rayleigh fractionation in each step, to explain the $\delta^{18} \mathrm{O}$ 
values measured on the Quelccaya ice cap. They concluded that air circulation and air mass stability, rather than temperature, determine the seasonal $\delta^{18} \mathrm{O}$ cycle over Quelccaya. They did not address the longer-term relationship between $\delta^{18} \mathrm{O}$ and $T_{\mathrm{a}}$ in the tropics that appears consistent with that in the higher latitudes (more negative $\delta^{18} \mathrm{O}$ implies colder $T_{\mathrm{a}}$ at condensation). Thompson and others (2000) suggest that seasonal changes in the cycle of deep tropical convection modulate the height of the mean condensation level (hence temperature of condensation). Deep summer convection produces precipitation that is more isotopically depleted than winter precipitation that condenses at lower levels in the atmosphere. Henderson and others (1999) and Vuille and others (2003) have investigated the controls on recent snowfall over Sajama, Quelccaya and Huascarán. Henderson and others (1999) note that the spatial distribution of temperature anomalies in the western tropical Atlantic influences atmospheric circulation at $500 \mathrm{hPa}$ and thereby isotopic fractionation over the Amazon Basin, the primary source of precipitation for Huascarán and Quelccaya. Vuille and others (2003) note that their modeled $\delta^{18} \mathrm{O}$ values depend strongly on precipitation amount, but conclude that the $\delta^{18} \mathrm{O}$ signal in precipitation is influenced by a combination of mechanisms (precipitation amount, temperature, variability of the moisture source and changes in atmospheric circulation). Bradley and others (2003) report strong linkages between sea surface temperatures across the equatorial Pacific Ocean and $\delta^{18} \mathrm{O}$ in ice cores from the tropical Andes as well as the Himalaya (Dasuopu glacier). They, like Henderson and others (1999), report a strong link between $\delta^{18} \mathrm{O}$ and El Niño-Southern Oscillation (ENSO) variability, which is not surprising as ENSO integrates all the mechanisms mentioned above. The $\delta^{18} \mathrm{O}-T_{\mathrm{a}}$ relationship on longer timescales (decades to centuries) is of greater importance here. Thompson and others $(2000,2003)$ present evidence that on longer timescales, $\delta^{18} \mathrm{O}$ variations in Andean precipitation more strongly reflect variations in air temperature than precipitation. Nevertheless, this issue is ripe for further investigation, as the dearth of records and their short duration present challenges to fully addressing the controls on the $\delta^{18} \mathrm{O}-T_{\mathrm{a}}$ relationship at highelevation sites in the low latitudes. Here the trends in $\delta^{18} \mathrm{O}$, when averaged over decadal and longer timescales, are assumed to reflect primarily trends in air temperature rather than in precipitation.

\section{DISCUSSION}

Placing the well-documented 20th-century warming of the Earth's globally averaged temperature within a temporal perspective longer than existing meteorological (Jones and Moberg, 2003) and oceanographic (Levitus and others, 2000) observations ( $\sim 1860$ to the present) requires proxy records such as ice-core-derived $\delta^{18} \mathrm{O}$ histories. Figure 1 reveals that the averaged $\delta^{18} \mathrm{O}$ for post-1900 precipitation is enriched (to differing degrees) relative to that for pre-1901 precipitation in all cores except those from Siple Station, West Antarctica, and Plateau Remote, East Antarctica. The observed regional trends in temperatures and the associated ice-core-derived $\delta^{18} \mathrm{O}$ records are discussed below. If the 20th-century $\delta^{18} \mathrm{O}$ trends among the ice cores are broadly consistent with the contemporaneous temperature trends for their respective regions, then the earlier portions (pre-20thcentury) of the $\delta^{18} \mathrm{O}$ records should also reflect regional

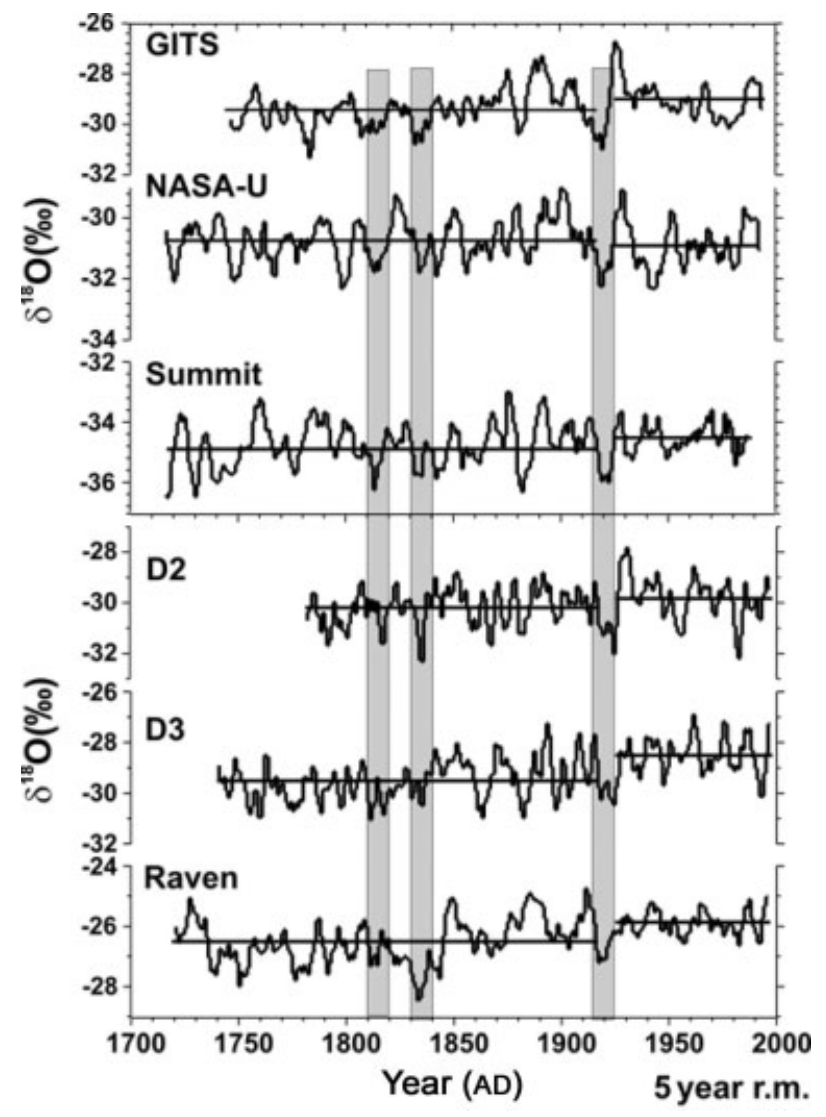

Fig. 2. The 5 year running mean of the annual $\delta^{18} \mathrm{O}$ histories from five new Greenland ice cores are shown along with the 1989 Site T record collected at the Summit (GISP2) site. Vertical shaded bars highlight specific time intervals discussed in the text. Horizontal bars in each record show the average $\delta^{18} \mathrm{O}$ value before and after the large cooling in 1917-19 that was followed by a rapid, widespread warming over much of the Arctic.

temperature trends and provide a viable longer-term perspective for the recent warming.

Large regional differences exist among the Greenland $\delta^{18} \mathrm{O}$ histories, even between the GISP2 and Summit 1989 records that are $\sim 4 \mathrm{~km}$ apart. The 20th-century enrichment appears larger in Summit 1989 than in GISP2, but this does not result from the different record lengths $(\sim 500$ vs $\sim 1000$ years, respectively). To facilitate comparison, the average $\delta^{18} \mathrm{O}$ value was calculated for the GISP2 segment that overlaps the Summit 1989 record, and, as Figure 1 reveals, the 500 year $\delta^{18} \mathrm{O}$ average is only slightly less than that for the 1000 year segment. Thus, the difference cannot be resolved with data in hand, and likely reflects some combination of differences in dating approaches, sampling schema and real spatial differences among the cores.

The 5 year unweighted running means of the annual $\delta^{18} \mathrm{O}$ values (Fig. 2) highlight the regional variability that exists over Greenland on annual to decadal timescales. This variability arises from (1) differences in regional climate forcing, (2) more localized conditions (e.g. an isotopic record is only produced when snow is falling), and (3) postdepositional modification by deflation, drifting and redeposition of surface snow. Despite this regional variability, the coherency of the Greenland $\delta^{18} \mathrm{O}$ records (Fig. 2) provides strong evidence that $\delta^{18} \mathrm{O}$ of the precipitation (snow) does reflect large-scale, multi-year variations in air temperature. 
The vertical bars in Figure 2 highlight three periods of marked isotopic depletion (cooling) that are widely recorded along the west side of the ice sheet from the northwest (GITS) to the southwest (Raven). The two closely spaced shaded bars highlight two decades of well-documented volcanically induced cooling: (1) 1810-20 with the eruptions of Unknown in 1809 and Tambora, Indonesia, in 1815 (Dai and others, 1991; Mosley-Thompson and others, 2003) and (2) 1830-40 with the eruptions of an unidentified volcano in $\sim 1832$ and Coseguina, Nicaragua, in 1835 (Cole-Dai and others, 1997). The third bar highlights a brief, but large and spatially coherent, cooling from 1917 to 1919 that is documented in Arctic temperature composites (see e.g. Jones and Moberg, 2003, fig. 2).

This brief cold event preceded an abrupt warming in the high Arctic $\left(60-90^{\circ} \mathrm{N}\right)$ from $\sim 1920$ to $\sim 1940$ (Rogers, 1985). The warming was strongest in the Kara and Barents Sea region and only slightly weaker in western Baffin Bay. It is hypothesized to have been linked to the retreat of sea ice in response to enhanced westerly flow (Bengtsson and others, 2004). Over the ice sheet the post-1920 warming is recorded by slightly enriched $\delta^{18} \mathrm{O}$ values at all sites except NASA-U (Fig. 2). Note that the $\delta^{18} \mathrm{O}$-inferred warming is most pronounced at the two southernmost sites (Raven and D3). The new Greenland $\delta^{18} \mathrm{O}$ records are relatively short and provide a limited temporal perspective, but when coupled with the longer records from Summit they suggest modest 20th-century warming over Greenland with alternating multi-decadal periods of warming and cooling, consistent with the limited available meteorological observations (for a summary see Box, 2002).

An ice-core record from the Windy Dome ice cap in FJL yields quite a different picture (Henderson, 2002). The decadally averaged $\delta^{18} \mathrm{O}$ record (Fig. 1) suggests a large warming that began 1910 and was sustained until midcentury, consistent with observations in the Barents Sea region as discussed above. Longer ice cores from this region are needed to assess the 20th-century warming relative to that associated with the Medieval Warm Period (MWP).

The available high-resolution $\delta^{18} \mathrm{O}$ records from Northern Hemisphere high-latitude ice cores are generally consistent with 20th-century observations. Specifically, they record (1) the short-term cooling in response to explosive tropical volcanic eruptions that injected sulfate aerosols into the tropical stratosphere where they were globally distributed, (2) the brief large-scale cooling from 1917 to 1919, and (3) the subsequent rapid (few years), large-scale warming in the Arctic (Rogers, 1985; Overpeck and others, 1997; Jones and Moberg, 2003) that persisted for several decades. Thus it is realistic to assume that $\delta^{18} \mathrm{O}$ variations in the pre-20thcentury part of the ice-core records also reflect regional temperature trends. The collection of annually dated $\delta^{18} \mathrm{O}$ records discussed here suggests that 20th-century warming has been spatially variable over Greenland but, on balance, temperatures have been modestly warmer than in previous centuries, particularly over the southern part of the ice sheet. With the exception of the two southern sites (D3 and Raven), the magnitude of the warming over the 20th century remains smaller than the decadal-scale variability. Eastward in the Russian Arctic, the FJL $\delta^{18} \mathrm{O}$ record suggests that 20thcentury warming in that high-Arctic region is well outside the norm for the last half-millennium.

Ice cores from tropical and subtropical regions are limited, but new cores are being slowly added to the archive. Two low-latitude ice-core $\delta^{18} \mathrm{O}$ composite records have been previously published (Thompson and others, 2003) and are included in Figure 1. The composite for the South American Andes is derived from the Quelccaya, Huascarán and Sajama cores, while the Tibetan Plateau composite is based on the Dunde, Guliya and Dasuopu cores. Note that these two composite $\delta^{18} \mathrm{O}$ histories reveal some notable regional differences over most of the last millennium. The Andean composite shows a clear Little Ice Age or recent neoglacial cool period (AD 1450-1880) as well as warmer conditions from $A D \sim 1100$ to 1350 , correlative with the MWP. The Tibetan composite shows neither of these multi-century climate variations. The only consistent, century-scale feature between the two regional composites is the marked isotopic enrichment in 20thcentury precipitation. Although high-resolution, well-dated tropical and subtropical ice-core records are scarce, they paint a consistent picture, specifically, that the 20th-century warming in the Andes and over the Tibetan Plateau is now outside the range of natural variability for the last millennium. The recent warming in lower-latitude, highelevation regions is consistent with atmospheric temperatures (Diaz and others, 2003; Jones and Moberg, 2003), Intergovernmental Panel on Climate Change model predictions (Cubasch and others, 2001) and the widespread recession of alpine glaciers (Thompson and others, 2003; Oerlemans, 2005).

The number of annually resolved and carefully dated $\delta^{18} \mathrm{O}$ records available from Antarctica is also limited. Three $\delta{ }^{18} \mathrm{O}$ records, each representing a different part of the continent, are shown in Figure 1. The annually dated Dyer Plateau (DP) core (Thompson and others, 1994) is located along the spine of the Antarctic Peninsula, a region where temperatures have increased strongly since the 1950s (Marshall and others, 2002; King and others, 2003). Temperature records here are short, with observations extending back to the late 1940s. The decadally averaged 500 year $\delta^{18} \mathrm{O}$ history suggests cooler temperatures from $\mathrm{AD} \sim 1700$ to 1950 , followed by ${ }^{18} \mathrm{O}$ enrichment that is contemporaneous with the observed warming in the region (Mosley-Thompson and Thompson, 2003). The 20th-century average $\delta^{18} \mathrm{O}$ value exceeds that for the previous 400 years, and the isotopically inferred warming of the last few decades lies well outside the range of natural variability for the last half-millennium.

On the high dry polar plateaus of East and West Antarctica, $\delta^{18} \mathrm{O}$ records are available from Plateau Remote and Siple Stations. At Siple Station (SS), the high annual accumulation $(461 \mathrm{~mm}$ w.e.) results in an excellently preserved and easily interpretable annual record (MosleyThompson, 1992). At Plateau Remote (PR), the low accumulation ( $\sim 40 \mathrm{~mm}$ w.e.) makes annual resolution difficult, but well-known time-stratigraphic volcanic horizons provide excellent time constraints for the last millennium (MosleyThompson, 1996; Cole-Dai and others, 2000). The $\delta^{18} \mathrm{O}$ history at PR shows a very modest ${ }^{18} \mathrm{O}$ depletion (cooling) in 20th-century precipitation relative to that over the last millennium, while the ${ }^{18} \mathrm{O}$ depletion is stronger at SS. Both suggest a recent cooling relative to the earlier part of the record. Antarctic meteorological records are short, few in number and biased toward coastal stations and stations in the Peninsula (Turner and others, 2005). Two long records exist for the interior of the continent (Vostok and AmundsenScott South Pole Station) and both show long-term cooling 
trends. At South Pole (SP), average annual near-surface temperatures have declined slowly by $\sim 0.5^{\circ} \mathrm{C}$ since record keeping began in 1958 although interannual variability is high (data provided to E.M.-T. by SP meteorological personnel in July 2005).

Thus, recent $\delta^{18} \mathrm{O}$ trends in Antarctic precipitation appear regionally consistent with the observed temperature trends. The recent ${ }^{18} \mathrm{O}$ enrichment in the DP core from the spine of the Peninsula and the modest ${ }^{18} \mathrm{O}$ depletion in the SS and PR cores on the high polar plateau are consistent with the warming and cooling trends observed in those regions, respectively (Vaughan and others, 2001 and references therein; Thompson and Solomon, 2002; Turner and others, 2005). Assuming that the earlier portions of these $\delta^{18} \mathrm{O}$ records also provide credible temperature proxies, the recent warming in the Peninsula region is unusual within the longer (500 years) perspective available, and the slight cooling in East and West Antarctica lies within the range of past variability (1000 years for PR and 500 years for SS).

\section{CONCLUSIONS}

High temporally resolved ice-core-derived $\delta^{18} \mathrm{O}$ records have been examined to assess whether they provide reliable proxies for examining regional 20th-century temperature trends within a longer-term perspective. The largest isotopically inferred warming is found in the Russian Arctic. Warmer 20th-century temperatures characterize the Tibetan Plateau and the South American Andes and extend into the Antarctic Peninsula. The 20th-century warming in these regions lies outside the range of natural variability as discerned from the earlier part of their respective $\delta^{18} \mathrm{O}$ records. Over Greenland a modest warming that is most pronounced over the southwestern part of the ice sheet has ensued since $\sim 1920$. Modest cooling has dominated 20thcentury temperatures over the high plateaus of East and West Antarctica. The unique climate histories preserved in the glaciers and ice caps from the Russian Arctic through the tropics to the Antarctic Peninsula may soon be degraded and/or lost if the current warming in those regions persists.

\section{ACKNOWLEDGEMENTS}

We thank the numerous scientists, engineers and field assistants who participated in the ice-core drilling projects that recovered these cores and conducted the laboratory analyses to extract the proxy records contained therein. Two anonymous reviewers provided valuable suggestions. These projects were funded over the years by the NSF, NASA, the US National Oceanic and Atmospheric Administration and the US National Geographic Society. This is Byrd Polar Research Center contribution No. 1325.

\section{REFERENCES}

Aldaz, L. and S. Deutsch. 1967. On a relationship between air temperature and oxygen isotope ratio of snow and firn in the South Pole region. Earth Planet Sci. Lett., 3(3), 267-274.

Bengtsson, L., V.A. Semenov and O.M. Johannessen. 2004. The early twentieth-century warming in the Arctic - A possible mechanism. J. Climate, 17, 4045-4057.

Box, J.E. 2002. Survey of Greenland instrumental temperature records: 1873-2001. Int. J. Climatol., 22(15), 1829-1847.
Bradley, R.S., M. Vuille, D. Hardy and L.G. Thompson. 2003. Low latitude ice cores record Pacific sea surface temperatures. Geophys. Res. Lett., 30(4), 1174. (10.1029/2002GL016546.)

Cole-Dai, J., E. Mosley-Thompson and L.G. Thompson. 1997. Annually resolved Southern Hemisphere volcanic history from two Antarctic ice cores. J. Geophys. Res., 102(D14), 16,761$16,771$.

Cole-Dai, J., E. Mosley-Thompson, S.P. Wight and L.G. Thompson. 2000. A 4100-year record of explosive volcanism from an East Antarctic ice core. J. Geophys. Res., 105(D19), 24,43124,441 .

Cubasch, U. and 8 others. 2001. Projections of future climate change. In Houghton, J.T. and 7 others, eds. Climate change 2001: the scientific basis. Contribution of Working Group I to the Third Assessment Report of the Intergovernmental Panel on Climate Change. Cambridge, Cambridge University Press, 525-582.

Cuffey, K.M., G.D. Clow, R.B. Alley, M. Stuiver, E.D. Waddington and R.W. Saltus. 1995. Large Arctic temperature change at the Wisconsin-Holocene glacial transition. Science, 270(5235), 455-458.

Dai, J., E. Mosley-Thompson and L.G. Thompson. 1991. Ice core evidence for an explosive tropical volcanic eruption 6 years preceding Tambora. J. Geophys. Res., 96(D9), 17,361-17,366.

Dansgaard, W., S.J. Johnsen, H.B. Clausen and N. Gundestrup. 1973. Stable isotope glaciology. Medd. Grønl., 197(2), 1-53.

Diaz, H.F., J.K. Eischeid, C. Duncan and R.S. Bradley. 2003. Variability of freezing levels, melting season indicators, and snow cover for selected high-elevation and continental regions in the last 50 years. Climatic Change, 59(1-2), 33-52.

Grootes, P.M., M. Stuiver, L.G. Thompson and E. MosleyThompson. 1989. Oxygen isotope changes in tropical ice, Quelccaya, Peru. J. Geophys. Res., 94(D1), 1187-1194.

Grootes, P.M., M. Stuiver, J.W.C. White, S. Johnsen and J. Jouzel. 1993. Comparison of oxygen isotope records from the GISP2 and GRIP Greenland ice cores. Nature, 366(6455), 552-554.

Hansen, J.E. and 7 others. 2001. A closer look at United States and global surface temperature change. J. Geophys. Res., 106(D20), 23,947-23,963.

Henderson, K.A. 2002. An ice core paleoclimate study of Windy Dome, Franz Josef Land (Russia): development of a recent climate history for the Barents Sea. (PhD thesis, Ohio State University.)

Henderson, K.A., L.G. Thompson and P.N. Lin. 1999. Recording of El Niño in ice core $\delta^{18} \mathrm{O}$ records from Nevado Huascarán, Peru. J. Geophys. Res., 104(D24), 31,053-31,065.

Johnsen, S.J., W. Dansgaard and J.W.C. White. 1989. The origin of Arctic precipitation under present and glacial conditions. Tellus, 41B(4), 452-468.

Jones, P.D. and A. Moberg. 2003. Hemispheric and large-scale surface air temperature variations: an extensive revision and an update to 2001. J. Climate, 16(2), 206-223.

Jouzel, J. 1999. Calibrating the isotopic paleothermometer. Science, 286(5441), 910-911.

Jouzel, J. and 12 others. 1997. Validity of the temperature reconstruction from water isotopes in ice cores. J. Geophys. Res., 102(C12), 26,471-26,487.

King, J.C., J. Turner, G.J. Marshall, W.M. Connolley and T.A. Lachlan-Cope. 2003. Antarctic Peninsula climate variability and its causes as revealed by analysis of instrumental records. In Domack, E.W., A. Burnett, A. Leventer, P. Conley, M. Kirby and R. Bindschadler, eds. Antarctic Peninsula climate variability: a historical and paleoenvironmental perspective. Washington, DC, American Geophysical Union, 17-30. (Antarctic Research Series 79.)

Levitus, S., J.I. Antonov, T.P. Boyer and C. Stephens. 2000. Warming of the world ocean. Science, 287(5461), 2225-2229.

Mann, M.E. and P.D. Jones. 2003. Global surface temperatures over the past two millennia. Geophys. Res. Lett., 30(15), 1820. (10.1029/2003GL017814.) 
Mann, M.E., R.S. Bradley and M.K. Hughes. 1999. Northern Hemisphere temperatures during the past millennium: inferences, uncertainties and limitations. Geophys. Res. Lett., 26(6), 759-762.

Marshall, G.J., V. Lagun and T.A. Lachlan-Cope. 2002. Changes in Antarctic Peninsula tropospheric temperatures from 1956 to 1999: a synthesis of observations and reanalysis data. Int. J. Climatol., 22(3), 291-310.

McConnell, J.R. and 6 others. 2001. Annual net snow accumulation over southern Greenland from 1975 to 1998. J. Geophys. Res., 106(D24), 33,827-33,838.

Moberg, A., D.M. Sonechkin, K. Holmgren, N.M. Datsenko and W. Karlén. 2005. Highly variable Northern Hemisphere temperatures reconstructed from low- and high-resolution proxy data. Nature, 433(7026), 613-617.

Mosley-Thompson, E. 1992. Paleoenvironmental conditions in Antarctica since A.D. 1500: ice core evidence. In Bradley, R.S. and P.D. Jones, eds. Climate since A.D. 1500. London and New York, Routledge, 572-591.

Mosley-Thompson, E. 1996. Holocene climate changes recorded in an East Antarctica ice core. In Jones, P.D., R.S. Bradley and J. Jouzel, eds. Climatic variations and forcing mechanisms of the last 2000 years. Berlin, Springer-Verlag, 263-279. (NATO Advanced Research Series 41.)

Mosley-Thompson, E. and L.G. Thompson. 2003. Ice core paleoclimate histories from the Antarctic Peninsula: Where do we go from here? In Domack, E., A. Burnett and A. Leventer, eds. Antarctic Peninsula climate variability: a historical and paleoenvironmental perspective. Washington, DC, American Geophysical Union, 115-127. (Antarctic Research Series 79.)

Mosley-Thompson, E., L.G. Thompson, J. Dai, M. Davis and P.N. Lin. 1993. Climate of the last 500 years: high resolution ice core records. Quat. Sci. Rev., 12(6), 419-430.

Mosley-Thompson, E. and 8 others. 2001. Local to regional-scale variability of annual net accumulation on the Greenland ice sheet from PARCA cores. J. Geophys. Res., 106(D24), 33,83933,851.

Mosley-Thompson, E., T.A. Mashiotta and L.G. Thompson. 2003. Ice core records of late Holocene volcanism: current and future contributions from the Greenland PARCA cores. In Robock, A. and C. Oppenheimer, eds. Volcanism and the Earth's atmosphere. Washington, DC, American Geophysical Union, 153164. (AGU Monograph 139.)

Oerlemans, J. 2005. Extracting a climate signal from 169 glacier records. Science, 308(5722), 675-677.

Overpeck, J. and 17 others. 1997. Arctic environmental change of the last four centuries. Science, 278(5341), 1251-1256.

Peel, D.A. 1992. Ice core evidence from the Antarctic Peninsula region. In Bradley, R.S. and P.D. Jones, eds. Climate since A.D. 1500. London and New York, Routledge, 549-571.

Rogers, J.C. 1985. Atmospheric circulation changes associated with the warming over the northern north-Atlantic in the 1920s. J. Appl. Meteorol., 24(12), 1303-1310.

Rozanski, K., L. Araguás-Araguás and R. Gonfiantini. 1992. Relation between long-term trends of oxygen-18 isotope composition of precipitation and climate. Science, 258(5084), 981-985.
Rozanski, K., L. Araguás-Araguás and R. Gonfiantini. 1993. Isotopic patterns in modern global precipitation. In Swart, P.K., K.C. Lohmann, J.A. McKenzie and S. Savin, eds. Climate change in continental isotopic records. Washington, DC, American Geophysical Union, 1-36. (Geophysical Monograph 78.)

Rozanski, K., S.J. Johnsen, U. Schotterer and L.G. Thompson. 1997. Reconstruction of past climates from stable isotope records of palaeo-precipitation preserved in continental archives. Journal des Sciences Hydrologiques, 42(5), 725-745.

Thomas, R.H. and PARCA Investigators. 2001. Program for Arctic Regional Climate Assessment (PARCA): goals, key findings, and future directions. J. Geophys. Res., 106(D24), 33,69133,705 .

Thompson, D.W.J. and S. Solomon. 2002. Interpretation of recent Southern Hemisphere climate change. Science, 296(5569), 895-899.

Thompson, L.G., E. Mosley-Thompson, W. Dansgaard and P.M. Grootes. 1986. The Little Ice Age as recorded in the stratigraphy of the tropical Quelccaya ice cap. Science, 234(4774), 361-364.

Thompson, L.G. and 8 others. 1989. 100,000 year climate record from Qinghai-Tibetan Plateau ice cores. Science, 296(4929), 474-477.

Thompson, L.G. and 7 others. 1994. Climate since AD 1510 on Dyer Plateau, Antarctic Peninsula: evidence for recent climate change. Ann. Glaciol., 20, 420-426.

Thompson, L.G. and 7 others. 1995. Late glacial stage and Holocene tropical ice core records from Huascarán, Peru. Science, 269(5220), 46-50.

Thompson, L.G. and 9 others. 1997. Tropical climate instability: the last glacial cycle from a Qinghai-Tibetan ice core. Science, 276(5320), 1821-1825.

Thompson, L.G. and 11 others. 1998. A 25,000-year tropical climate history from Bolivian ice cores. Science, 282(5395), 1858-1864.

Thompson, L.G., E. Mosley-Thompson and K.A. Henderson. 2000. Ice-core palaeoclimate records in tropical South America since the Last Glacial Maximum. J. Quat. Sci., 15(4), 377-394.

Thompson, L.G., E. Mosley-Thompson, M.E. Davis, P.N. Lin, K. Henderson and T.A. Mashiotta. 2003. Tropical glacier and ice core evidence of climate change on annual to millennial timescales. Climatic Change, 59(1-2), 137-155.

Turner, J. and 8 others. 2005. Antarctic climate change during the last 50 years. Int. J. Climatol., 25, 279-294.

Vaughan, D.G., G.J. Marshall, W.M. Connolley, J.C. King and R. Mulvaney. 2001. Climate change: devil is in the detail. Science, 293(5536), 1777-1779.

Vuille, M. and 6 others. 2003. Modeling $\delta^{18} \mathrm{O}$ in precipitation over the tropical Americas: 2. Simulation of the stable isotope signal in Andean ice cores. J. Geophys. Res., 108(D6), 4175. (10.1029/ 2001JD002039.)

Yao, T., L.G. Thompson, E. Mosley-Thompson, Y. Zhihong, Z. Xingping and P.N. Lin. 1996. Climatological significance of $\delta^{18} \mathrm{O}$ in north Tibetan ice cores. J. Geophys. Res., 101(D23), $29,531-29,537$. 